\title{
ANALISIS PENGARUH STRES KERJA, BEBAN KERJA DAN LINGKUNGAN KERJA TERHADAP TURNOVER INTENTION KARYAWAN PADA PT XL AXIATA TBK JAKARTA
}

\author{
Laksmi Sito Dwi Irvianti; Renno Eka Verina \\ Management Department, School of Business Management, BINUS University \\ Jln. K.H. Syahdan No.9, Palmerah, Jakarta Barat 11480 \\ laksmisito@yahoo.com enoverina@hotmail.com
}

\begin{abstract}
This study aims to determine the effect of job stress, workload and work environment to employee turnover intention PT XL Axiata Tbk Jakarta. This study used survey research and data collection technique used are observation, interviews, literature studies and questionnaires distributed through 81 employees as respondents. The collected data was analyzed by using simple and multiple regression. From the research, it is known variables $X 1$ (job stress) partially influence on the variable $Y$ (turnover intention). The X2 variable (workload) partially influence variable $Y$ (turnover intention). While the X3 variable (work environment) partially influence variable $Y$ (turnover intention) And unknown variables X1 (job stress), X2 (workload) and X3 (work environment) influences variable Y (turnover intention) simultaneously.
\end{abstract}

Keywords: job stress, workload, work environment

\begin{abstract}
ABSTRAK
Penelitian ini bertujuan untuk mengetahui pengaruh stres kerja, beban kerja dan lingkungan kerja terhadap turnover intention karyawan PT XL Axiata Tbk Jakarta. Penelitian ini menggunakan metode penelitian survei dan teknik pengumpulan data yang digunakan ialah observasi, wawancara, studi kepustakaan dan kuesioner. Populasi dalam penelitian ini adalah seluruh karyawan PT XL Axiata Tbk Jakarta yang berjumlah 402 orang. Sedangkan sampel dalam penelitian sebanyak 81 orang karyawan yang ukuran sampel ditentukan melalui rumus Slovin. Metode analisis yang digunakan ialah regresi sederhana dan regresi berganda. Dari hasil penelitian, diketahui variabel X1 (stres kerja) secara parsial berpengaruh terhadap variabel Y (turnover intention). Variabel X2 (beban kerja) secara parsial berpengaruh terhadap variabel Y (turnover intention). Variabel X3 (lingkungan kerja) secara parsial berpengaruh terhadap variabel Y (turnover intention). Dan diketahui variabel X1 (stres kerja), X2 (beban kerja) dan X3 (lingkungan kerja) mempengaruhi variabel Y (turnover intention) secara simultan.
\end{abstract}

Kata kunci: stres kerja, beban kerja, lingkungan kerja, turnover intention 


\section{PENDAHULUAN}

Manusia merupakan mahluk sosial. Pada dasarnya, manusia memiliki dorongan untuk berinteraksi satu dengan yang lain dan tidak dapat melepaskan diri dari pengaruh manusia lain. Berdasarkan hal tersebut, manusia tidak akan pernah lepas dari kehidupan berorganisasi dan bermasyarakat. Hal ini telihat jelas dalam kehidupan sehari-hari, lingkungan rumah tangga, organisasi sosial, organisasi pendidikan atau bahkan organisasi tempat berkerja. Untuk mencapai tujuan, setiap organisasi memerlukan sumber daya. Sumber daya adalah suatu nilai potensi yang dimiliki oleh suatu materi atau unsur tertentu dalam kehidupan. Sumber daya itu antara lain sumber daya alam, sumber daya finansial, sumber daya ilmu pengetahuan dan teknologi, serta sumber daya manusia.

Manajemen sumber daya manusia merupakan suatu proses untuk menangani berbagai masalah dalam ruang lingkup kerja untuk dapat menunjang aktifitas organisasi atau perusahaan agar mencapai tujuan yang telah ditentukan. Manusia merupakan salah satu unsur yang penting di dalam suatu organisasi, karena manusia merupakan penggerak dan penentu jalannya suatu organisasi. Unsur manajemen sumber daya manusia adalah individu yang merupakan tenaga kerja pada perusahaan. Dengan demikian, fokus yang dipelajari oleh sumber daya manusia adalah masalah yang berpengaruh dengan tenaga kerja manusia.

Salah satu masalah yang berpengaruh dengan tenaga kerja dalam suatu perusahaan adalah tingkat turnover yang tinggi. Turnover atau pergantian tenaga kerja merupakan wujud nyata dari turnover intention yang dapat menjadi masalah serius bagi perusahaan atau organisasi, khususnya apabila yang keluar adalah tenaga kerja yang mempunyai keahlian, kemampuan, terampil dan berpengalaman atau tenaga kerja yang menduduki posisi vital dalam perusahaan, sehingga dapat menganggu efektivitas jalannya perusahaan.

Staffelbach (2008) menguraikan turnover intention merupakan kemungkinan yang bersifat subyektif dimana seorang individu akan merubah pekerjaannya dalam jangka waktu tertentu dan merupakan pelopor dasar kepada turnover yang sebenarnya. Stres kerja, beban kerja dan lingkungan kerja merupakan variabel penting yang berpengaruh dengan turnover intention karyawan. Dalam perkembangannya, stres kerja, beban kerja dan lingkungan kerja harus diperhatikan oleh perusahaan untuk membuat karyawan yang bekerja dalam perusahaan tersebut merasa nyaman dalam bekerja.

Berdasarkan latar belakang yang sudah tertulis di atas, rumusan masalah yang akan dibahas dalam penelitian ini adalah apakah ada pengaruh secara parsial dan simultan antara stres kerja, beban kerja dan lingkungan kerja terhadap turnover intention karyawan pada PT XL Axiata Tbk Jakarta

\section{Landasan Teori}

Stres kerja dilambangkan sebagai kekuatan, tekanan, kecenderungan atau upaya seseorang dalam kekuatan mental pada pekerjaannya (Salleh, Bakar dan Keong, 2008). Secara umum, seseorang mengalami stres pada pekerjaan akan menampilkan gejala-gejala yang meliputi tiga kategori umum, yaitu (Robbins dan Judge, 2008): (1) Gejala Fisiologis. Gejala fisiologis merupakan gejala awal yang bisa diamati, terutama pada penelitian medis dan ilmu kesehatan. Stres cenderung berakibat pada perubahan metabolisme tubuh, meningkatnya detak jantung dan pernafasan, peningkatan tekanan darah, timbulnya sakit kepala, serta yang lebih berat lagi terjadinya serangan jantung. (2) Gejala Psikologis. Dari segi psikologis, stres dapat menyebabkan ketidakpuasan. Hal itu merupakan efek psikologis yang paling sederhana dan paling jelas. Namun bisa saja muncul keadaan psikologis lainnya, misalnya ketegangan, kecemasan, mudah marah, kebosanan dan suka menunda-nunda pekerjaan. Bukti menunjukkan bahwa ketika orang ditempatkan dalam pekerjaan dengan tuntutan yang banyak dan saling bertentangan atau dimana ada ketidakjelasan tugas, wewenang, dan tanggung 
jawab pemegang jabatan, maka stres maupun ketidakpuasan akan meningkat. (3) Gejala Perilaku. Gejala stres yang berkaitan dengan perilaku meliputi perubahan dalam tingkat produktivitas, absensi, kemangkiran, dan tingkat keluarnya karyawan, juga perubahan dalam kebiasaan makan, merokok dan konsumsi alkohol, bicara cepat, gelisah, dan gangguan tidur.

Indikator stres kerja menurut Salleh, Bakar dan Keong (2008) terbagi atas 5 skala penilaian yaitu: (1) Faktor intrinsik pekerjaan yang terbagi atas tuntutan tugas, tekanan waktu karena deadline pekerjaan dan harus melakukan pengambilan keputusan yang terlalu banyak. (2) Peran dalam organisasi yang terbagi atas ketidakpastian dan kurangnya informasi peran pekerjaan, harapan dalam pekerjaan dan tanggung jawab dalam pekerjaan. (3) Hubungan di tempat kerja yang terbagi atas hubungan dengan atasan dan hubungan dengan rekan kerja. (4) Pengembangan karir yang terbagi atas kurangnya keamanan kerja (ketakutan akan tidak dipakai lagi atau pensiun dini) dan ketidakcocokan status misalnya promosi yang berlebihan, promosi yang kurang dan frustasi karena harus mengejar karir yang tinggi. (5) Struktur dan iklim organisasi yaitu kesempatan yang lebih besar untuk berpartisipasi dalam pengambilan keputusan.

Beban kerja adalah besaran pekerjaan yang harus dipikul oleh suatu jabatan atau unit organisasi dan merupakan hasil kali antara volume kerja dan norma waktu (Soleman, 2011). Soleman (2011) mengembangkan beban kerja dalam 2 skala penilaian, yaitu: (1) Faktor eksternal yang terbagi atas tugas-tugas yang diberikan, kompleksitas pekerjaan, lamannya waktu kerja dan istirahat. (2) Faktor internal yang terbagi atas motivasi, persepsi, keinginan dan kepuasaan.

Imran et. al. (2013) menemukan bahwa terdapat hubungan yang signifikan antara beban kerja dan stres kerja, serta stres kerja dan turnover intention. Penelitian tersebut mengasumsikan bahwa stres kerja memainkan peran tengah antara beban kerja dan turnover intention. Lingkungan kerja adalah semua yang terdapat disekitar tempat kerja yang dapat mempengaruhi pegawai baik secara langsung maupun tidak langsung (Sedarmayanti, 2007).

Sedarmayanti (2011) menyatakan bahwa terdapat beberapa faktor yang dapat mempengaruhi terbentuknya suatu kondisi lingkungan kerja dikaitkan dengan kemampuan manusia/pegawai, di antaranya adalah penerangan/cahaya di tempat kerja, temperatur di tempat kerja, kelembaban di tempat kerja, sirkulasi udara di tempat kerja, kebisingan di tempat kerja, getaran mekanis di tempat kerja, bau-bauan di tempat kerja, tata warna di tempat kerja, dekorasi di tempat kerja, dan musik di tempat kerja.

\section{Penerangan/Cahaya di Tempat Kerja}

Cahaya atau penerangan sangat besar manfaatnya bagi pegawai guna mendapat keselamatan dan kelancaran kerja. Oleh sebab itu perlu diperhatikan adanya penerangan (cahaya) yang terang tetapi tidak menyilaukan. Cahaya yang kurang jelas (kurang cukup) mengakibatkan penglihatan menjadi kurang jelas, sehingga pekerjaan akan berjalan lambat, banyak mengalami kesalahan, dan pada akhirnya menyebabkan kurang efisien dalam melaksanakan pekerjaan, sehingga tujuan organisasi sulit dicapai.

\section{Temperatur di Tempat Kerja}

Dalam keadaan normal, tiap anggota tubuh manusia mempunyai temperatur berbeda. Tubuh manusia selalu berusaha untuk mempertahankan keadaan normal, dengan suatu sistem tubuh yang sempurna sehingga dapat menyesuaikan diri dengan perubahan yang terjadi di luar tubuh. Tetapi kemampuan untuk menyesuaikan diri tersebut ada batasnya, yaitu bahwa tubuh manusia masih dapat menyesuaikan dirinya dengan temperatur luar jika perubahan temperatur luar tubuh tidak lebih dari 20\% untuk kondisi panas dan 35\% untuk kondisi dingin, dari keadaan normal tubuh. 


\section{Kelembaban di Tempat Kerja}

Kelembaban adalah banyaknya air yang terkandung dalam udara, biasa dinyatakan dalam presentase. Kelembaban ini berpengaruh atau dipengaruhi oleh temperatur udara, dan secara bersamasama antara temperatur, kelembaban, kecepatan udara bergerak, dan radiasi panas dari udara tersebut akan mempengaruhi keadaan tubuh manusia pada saat menerima atau melepaskan panas dari tubuhnya. Suatu keadaan dengan temperatur udara sangat panas dan kelembaban tinggi, akan menimbulkan pengurangan panas dari tubuh secara besar-besaran karena sistem penguapan. Pengaruh lain adalah makin cepatnya denyut jantung karena makin aktifnya peredaran darah untuk memenuhi kebutuhan oksigen, dan tubuh manusia selalu berusaha untuk mencapai keseimbangan antara panas tubuh dengan suhu di sekitarnya.

\section{Sirkulasi Udara di Tempat Kerja}

Oksigen merupakan gas yang dibutuhkan oleh makhluk hidup untuk menjaga kelangsungan hidup, yaitu untuk proses metabolisme. Udara di sekitar dikatakan kotor apabila kadar oksigen dalam udara tersebut telah berkurang dan telah bercampur dengan gas atau bau-bauan yang berbahaya bagi kesehatan tubuh. Kotornya udara dapat dirasakan dengan sesak napas, dan ini tidak boleh dibiarkan berlangsung terlalu lama, karena akan mempengaruhi kesehatan tubuh dan akan mempercepat proses kelelahan. Sumber utama adanya udara segar adalah adanya tanaman di sekitar tempat kerja. Tanaman merupakan penghasil oksigen yang dibutuhkan oleh manusia. Dengan cukupnya oksigen di sekitar tempat kerja, ditambah dengan pengaruh secara psikologis akibat adanya tanaman di sekitar tempat kerja, keduanya akan memberikan kesejukan dan kesegaran pada jasmani. Rasa sejuk dan segar selama bekerja akan membantu mempercepat pemulihan tubuh akibat lelah setelah bekerja.

\section{Kebisingan di Tempat Kerja}

Salah satu polusi yang cukup menyibukkan para pakar untuk mengatasinya adalah kebisingan, yaitu bunyi yang tidak dikehendaki oleh telinga. Tidak dikehendaki, karena terutama dalam jangka panjang bunyi tersebut dapat mengganggu ketenangan bekerja, merusak pendengaran, dan menimbulkan kesalahan komunikasi, bahkan menurut penelitian, kebisingan yang serius bisa menyebabkan kematian. Karena pekerjaan membutuhkan konsentrasi, maka suara bising hendaknya dihindarkan agar pelaksanaan pekerjaan dapat dilakukan dengan efisien sehingga produktivitas kerja meningkat. Ada tiga aspek yang menentukan kualitas suatu bunyi, yang bisa menentukan tingkat gangguan terhadap manusia, yaitu: lamanya kebisingan, intensitas kebisingan, dan frekuensi kebisingan.

\section{Getaran Mekanis di Tempat Kerja}

Getaran mekanis artinya getaran yang ditimbulkan oleh alat mekanis, yang sebagian dari getaran ini sampai ke tubuh pegawai dan dapat menimbulkan akibat yang tidak diinginkan. Getaran mekanis pada umumnya sangat mengganggu tubuh karena ketidakteraturannya, baik tidak teratur dalam intensitas maupun frekuensinya. Secara umum getaran mekanis dapat mengganggu tubuh dalam hal konsentrasi bekerja, datangnya kelelahan, timbulnya beberapa penyakit diantaranya karena gangguan terhadap: mata, syaraf, peredaran darah, otot, tulang, dan lain-lain.

\section{Bau-bauan di Tempat Kerja}

Adanya bau-bauan di sekitar tempat kerja dapat dianggap sebagai pencemaran, karena dapat mengganggu konsentrasi bekerja, dan bau-bauan yang terjadi terus menerus dapat mempengaruhi kepekaan penciuman. Pemakaian air condition yang tepat merupakan salah satu cara yang dapat digunakan untuk menghilangkan bau-bauan yang menggangu di sekitar tempat kerja. 


\section{Tata Warna di Tempat Kerja}

Menata warna di tempat kerja perlu dipelajari dan direncanakan dengan sebaik-baiknya. Pada kenyataannya tata warna tidak dapat dipisahkan dengan penataan dekorasi. Hal ini dapat dimaklumi karena warna mempunyai pengaruh besar terhadap perasaan. Sifat dan pengaruh warna kadangkadang menimbulkan rasa senang, sedih, dan lain-lain, karena dalam sifat warna dapat merangsang perasaan manusia. Selain warna merangsang emosi atau perasaan, warna dapat memantulkan sinar yang diterimanya. Banyak atau sedikitnya pantulan dari cahaya tergantung dari macam warna itu sendiri.

\section{Dekorasi di Tempat Kerja}

Dekorasi ada pengaruhnya dengan tata warna yang baik, karena itu dekorasi tidak hanya berkaitan dengan hiasan ruang kerja saja tetapi berkaitan juga dengan cara mengatur tata letak, tata warna, perlengkapan dan lainnya untuk bekerja.

\section{Musik di Tempat Kerja}

Menurut para pakar musik yang nadanya lembut sesuai dengan suasana, waktu dan tempat dapat membangkitkan dan merangsang pegawai untuk bekerja. Oleh karena itu lagu-lagu perlu dipilih dengan selektif untuk dikumandangkan di tempat kerja. Tidak sesuainya musik yang diperdengarkan di tempat kerja akan mengganggu konsentrasi kerja.

Indikator dari lingkungan kerja menurut Sedarmayanti (2007) terbagi atas 2 skala pengukuran, yaitu: (1) Lingkungan kerja fisik yang terbagi atas penerangan/cahaya ditempat kerja, temperatur/suhu diruang kerja, kelembaban, sirkulasi udara, kebisingan, setaran mekanis, bau tidak sedap, tata warna, dekorasi, musik dan keamanan. (2) Lingkungan kerja non fisik yang terbagi atas pengaruh kerja terhadap karyawan dengan atasan, pengaruh kerja terhadap sesama karyawan dan pengaruh kerja terhadap atasan dengan karyawan.

Lingkungan kerja yang tidak membuat nyaman karyawan menjadi alasan turnover intention yang tinggi di antara karyawan. Kualitas pengawasan di dalam lingkungan kerja merupakan pengaruh yang signifikan terhadap turnover intention karyawan. Kurangnya pengawasan dan dukungan dari atasan dalam melakukan tugas akan mengarah pada tingkat turnover intention (Imran et. al., 2013). Turnover intention merupakan keinginan karyawan untuk pindah dari satu tempat kerja ke tempat kerja lainnya (Widjaja, 2012).

Menurut Lum et. al., (dalam Widjaja, 2012) intensi keluar merupakan variabel yang paling berhubungan dan lebih banyak menjelaskan perilaku turnover, dimana keinginan untuk keluar dapat diukur dengan 3 komponen berikut ini: (1) Keinginan untuk mencari pekerjaan baru di bidang yang sama di perusahaan lain. Melihat adanya perusahaan lain yang dirasa mampu memberikan keuntungan lebih banyak dibandingkan tempat dia bekerja saat ini, dapat menjadi alasan utama bagi individu untuk memicu keinginannya keluar dari perusahaan. Namun hal itu akan terbatas di saat dia hanya akan menerima jika sesuai dengan keahliannya saat ini. (2) Keinginan untuk mencari pekerjaan baru di bidang yang berbeda di perusahaan lain. Seorang individu yang merasa selama ini kurang mengalami kemajuan pada pekerjaan akan mencoba untuk beralih pada bidang yang berbeda. Tanpa harus mempelajari keahlian baru, individu tersebut mencari pekerjaan di bidang yang baru dengan keahlian sama dengan yang dia miliki saat ini. (3) Keinginan untuk mencari profesi baru. Dengan memiliki keahlian yang cukup banyak, maka akan mudah bagi seseorang untuk timbul keinginan mencari pekerjaan baru yang sebelumnya tidak pernah dia kerjakan.

Berdasarkan hasil penelitian yang dilakukan oleh Quereshi, Iftikhar, Abbas, Umar Hassan, Khan dan Zaman (2013) menunjukkan bahwa turnover intention berhubungan positif dengan stres 
kerja. Dengan meningkatnya stres kerja, turnover intention karyawan juga meningkat. Apabila perusahaan bersedia untuk mempertahankan modal intelektual, maka perusahaan harus mengurangi stres pekerjaan yang dapat menyebabkan stres kerja dan pada akhirnya dapat menyebabkan turnover karyawan. Faktor utama lainnya adalah beban kerja yang positif terkait dengan keinginan turnover karyawan. Beban kerja yang rasional adalah win-win situation bagi perusahan. Hasil studi memberikan bukti empiris, karyawan yang berpikir untuk meninggalkan pekerjaan karena mereka merasakan beban yang berlebihan. Demikian pula dengan lingkungan kerja juga merupakan faktor kunci untuk mempertahankan karyawan. Studi juga membuktikan bahwa lingkungan kerja yang baik dan kesehatan akan menyebabkan rendahnya keinginan turnover karyawan.

\section{METODE}

Jenis penelitian yang digunakan dalam penelitian ini adalah penelitian asosiatif, karena tujuan dari penelitian ini adalah untuk mengetahui pengaruh antara tiga variabel yaitu stres kerja, beban kerja dan lingkungan kerja terhadap variabel turnover intention karyawan. Unit analisis adalah tempat dimana penelitian diadakan, yang menjadi unit analisis dalam penelitian ini adalah karyawan PT XL Axiata Tbk Jakarta di Menara Prima.

Operasionalisasi variabel adalah penjabaran dari variabel yang diteliti, dimensi dan indikator yang digunakan untuk mengukur variabel tersebut. Dalam penelitian ini terdapat empat variabel yang digunakan, yaitu stres kerja, beban kerja, lingkungan kerja dan turnover intention. Variabel stres kerja memiliki lima dimensi, yaitu faktor intrinsik, peran dalam organisasi, hubungan di tempat kerja, pengembangan karir, serta struktur dan iklim organisasi. Sedangkan dimensi dari variabel beban kerja adalah faktor eksternal dan internal. Sperti halnya varibel beban kerja, varibel lingkungan kerja uga memiliki dua dimensi, yaitu lingkungan kerja fisik dan non fisik. Untuk varibel tunover intention, dimensinya adalah keinginan untuk mencari pekerjaan baru di bidang yang sama di perusahaan lain, keinginan untuk mencari pekerjaan baru di bidang lain di perusahaan lain, serta keinginan untuk mencari profesi baru.

Sumber data penelitian ini ada dua jenis yaitu data primer dan data sekunder. Menurut Sekaran (2006), data primer adalah informasi yang bisa didapatkan dari pembicaraan dengan orang lain, observasi kejadian, orang, objek; atau memberikan kuesioner kepada orang-orang. Jumlah keseluruhan karyawan PT.XL Axiata Tbk adalah 402 orang karyawan. Dengan presentase toleransi ketidaktelitian sebesar 10\%, maka sesuai rumus Slovin jumlah karyawan yang dijadikan sampel penelitian adalah sebanyak 81 orang karyawan dengan teknik sampling adalah simple random sampling. Data yang telah diperoleh kemudian dilakukan uji validitas, reliabilitas serta uji asumsi klasik yang kemudian dianalisa menggunakan metode regresi sederhana dan berganda. 


\section{HASIL DAN PEMBAHASAN}

Tabel 1 Bagan Pengaruh X1, X2 dan X3 terhadap Y

\begin{tabular}{rrlc}
\hline Variabel & Korelasi & \multicolumn{1}{c}{ Tingkat Hubungan } & Koefisien Determinasi \\
\hline $\mathrm{X} 1 \rightarrow \mathrm{Y}$ & 0,918 & Sangat kuat dan searah & $84,27 \%$ \\
$\mathrm{X} 2 \rightarrow \mathrm{Y}$ & 0,865 & Sangat kuat dan searah & $74,82 \%$ \\
$\mathrm{X} 3 \rightarrow \mathrm{Y}$ & $-0,899$ & Sangat kuat dan tidak searah & $80,82 \%$ \\
$\mathrm{X} 1, \mathrm{X} 2, \mathrm{X} 3 \rightarrow \mathrm{Y}$ & 0,960 & $\begin{array}{l}\text { Sangat kuat dan bersama-sama } \\
\text { mempengaruhi variabel turnover } \\
\text { intention }\end{array}$ & $91,90 \%$ \\
\hline
\end{tabular}

Sumber: Hasil Pengolahan Data, 2014

Hasil analisis dalam penelitian ini menggunakan program SPSS yaitu regresi sederhana dan regresi berganda yang hasilnya dapat dilihat dalam bagan sebagai berikut :

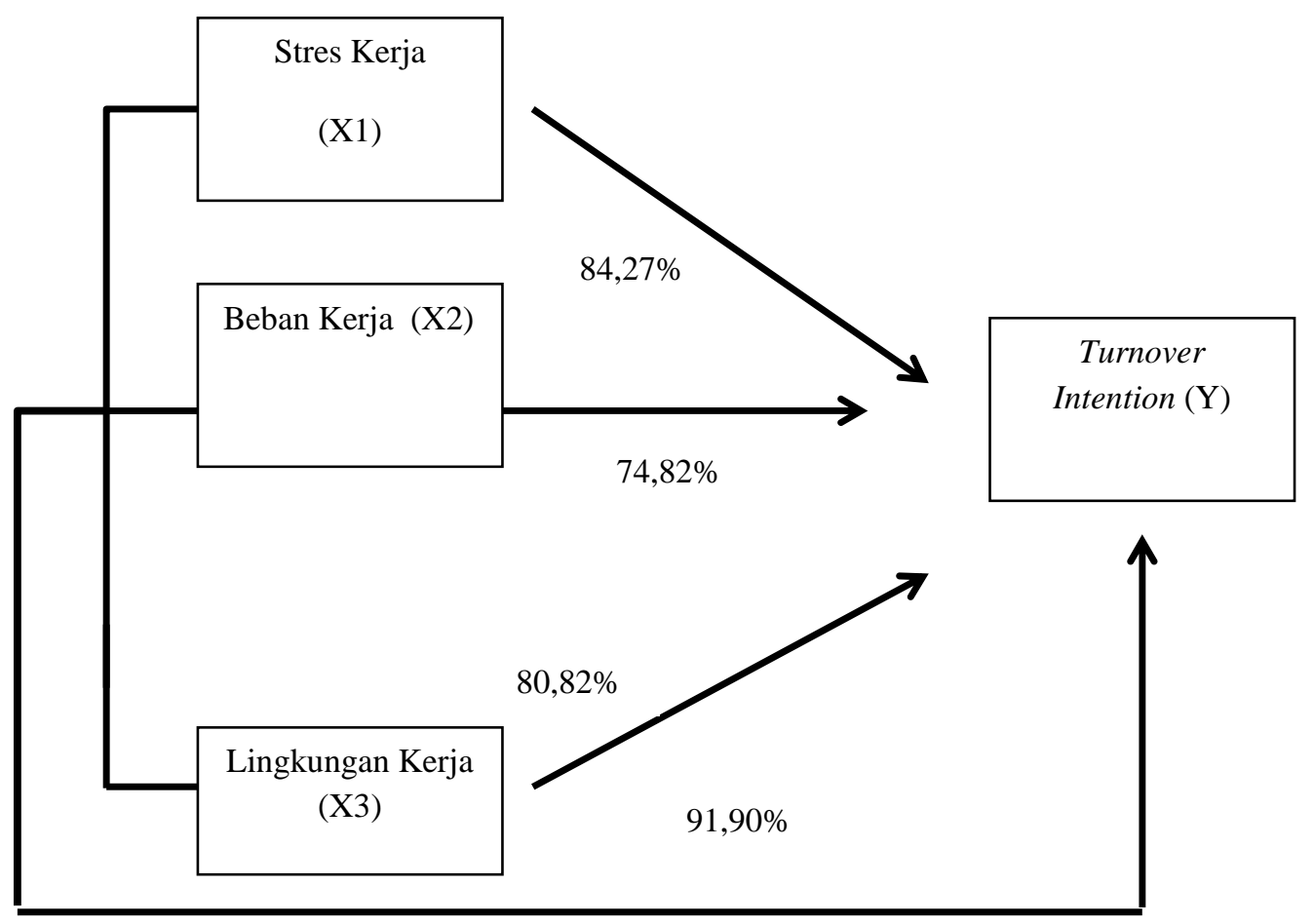

Gambar 1 Bagan Pengaruh X1, X2 dan X3 terhadap Y

Sumber: Hasil Output SPSS, 2014 
Hasil penelitian menunjukkan bahwa ketiga variabel independen, yaitu stres kerja, beban kerja, dan lingkungan kerja, secara parsial dan simultan. memiliki pengaruh terhadap turnover intention, yang secara parsial variabel stres kerja memiliki pengaruh paling besar dibandingkan dengan variabel independen lain. Dari uji korelasi diketahui bahwa variabel stres kerja dan beban kerja memiliki hubungan yang sangat kuat dan searah dengan variabel turnover intention, yang berarti bahwa jika stres kerja dan beban kerja semakin tinggi maka keinginan karyawan untuk keluar (turnover intention) juga akan meningkat dan sebaliknya. Sedangkan variabel lingkungan kerja juga memiliki hubungan yang sangat kuat, namun tidak searah, dengan varibel turnover intention yang berarti bahwa jika lingkungan kerja yang dirasakan karyawan semakin baik atau nyaman, maka keinginan karyawan untuk keluar (turnover intention) akan menurun.

Berdasarkan hasil kuesioner yang telah di bagikan kepada 81 responden, karyawan merasa harapan dalam pekerjaan yang tinggi menyebabkan stres kerja. Hal ini disebabkan karena karyawan menginginkan pekerjaan yang lebih baik dari pekerjaan saat ini. Karyawan merasa promosi jabatan kurang diberikan oleh perusahaan sehingga karyawan tidak bisa berkembang. Karyawan juga sulit mendapatkan kenaikan jabatan karena sistem kerja yang tidak permanen sehingga membuat karyawan bekerja dalam sistem kontrak yang ditentukan oleh perusahaan dan sulit untuk mendapatkan posisi yang lebih baik karena waktu kontrak yang hanya sebentar. Stres dalam pekerjaan secara luas dipercaya menjadi faktor utama yang mempengaruhi kinerja karyawan dalam perusahaan sehingga dapat menjadi prediktor penting terhadap niat untuk meninggalkan tempat kerja.

Sedangkan untuk dimensi struktur dan iklim organisasi dalam variabel stres kerja memiliki tingkat yang paling rendah atau memiliki jawaban rata-rata paling rendah. Hal ini menujukkan bahwa karyawan memiliki kesempatan berpartisipasi dalam mengambil keputusan sehingga hal ini dapat mengurangi tingkat stres kerja karyawan. Secara garis besar, sebagian besar karyawan PT XL Axiata mengalami stres kerja, dan hanya sebagian kecil karyawan yang tidak mengalami stres dalam bekerja. Hasil ini berdasarkan jawaban yang paling sering dipilih oleh karyawan pada pernyataan mengenai variabel stres kerja yaitu dengan nilai rata-rata 4,15. Secara garis besar, sebagian besar karyawan PT XL Axiata merasakan beban kerja yang berat dan hanya sebagian kecil karyawan yang tidak merasa beban dalam bekerja. Hasil ini berdasarkan dari jawaban yang paling sering dipilih oleh karyawan pada pernyataan mengenai variabel beban kerja yaitu dengan nilai rata-rata 4,17.

Kuesioner yang telah dibagikan kepada 81 responden menunjukkan bahwa dimensi faktor eksternal dalam variabel beban kerja memiliki tingkat yang paling rendah atau memiliki jawaban ratarata paling kecil. Setelah dianalisis, diperoleh jawaban bahwa kurangnya waktu istirahat yang diberikan perusahaan dari seharusnya, karena perusahaan memiliki peraturan waktu istirahat dan biasanya karyawan memakai waktu istirahat untuk menyelesaikan tugas sehingga waktu istirahat mereka menjadi berkurang.

Sedangkan untuk dimensi faktor internal, dimensi ini memiliki tingkat yang paling tinggi atau memiliki jawaban rata-rata paling tinggi. Setelah dianalisis ternyata keinginan karyawan untuk pekerjaan yang lebih baik menjadi prediktor penting terhadap variabel beban kerja. Setelah dilakukan analisis ternyata kenaikan jenjang karir yang sulit karena sistem kerja kontrak yang diberikan oleh perusahaan kepada karyawan membuat karyawan menjadi kurang berkembang dan hal tersebut menyebabkan beban kerja.

Berdasarkan hasil kuesioner yang telah dibagikan kepada 81 responden, dimensi lingkungan kerja fisik dalam variabel lingkungan kerja memiliki tingkat yang paling rendah atau memiliki jawaban rata-rata paling kecil. Setelah dianalisis, diperoleh jawaban bahwa suhu ruangan di tempat kerja kurang sesuai dengan kondisi tubuh karyawan. Suhu ruangan di tempat kerja yang kurang sesuai dengan kondisi tubuh karyawan adalah suhu air conditioner $(a c)$ yang terlalu dingin sehingga menyebabkan karyawan merasa mengantuk dan membuat karyawan merasa malas dalam bekerja sehingga pekerjaan yang harus diselesaikan karyawan menjadi terganggu. 
Sedangkan untuk dimensi lingkungan kerja nonfisik memiliki tingkat yang paling tinggi atau memiliki jawaban rata-rata paling tinggi. Setelah dianalisis ternyata hubungan karyawan dengan rekan kerja berjalan dengan baik dan hal tersebut membuat karyawan merasa puas dalam bekerja. Hubungan dengan rekan kerja maupun atasan yang kurang baik dapat menyebabkan karyawan merasa tidak nyaman dalam bekerja dan hal tersebut dapat meningkatkan turnover intention karyawan. Maka dengan jelas dimensi lingkungan kerja nonfisik memiliki tingkat paling tinggi dan dirasakan sudah cukup puas dan tidak terjadi masalah dalam hal ini.

Hasil kuesioner yang telah dibagikan kepada 81 responden dihasilkan bahwa keinginan karyawan untuk mencari profesi baru dalam variabel turnover intention memiliki tingkat yang paling rendah atau memiliki jawaban rata-rata paling kecil. Setelah dianalisis, diperoleh jawaban bahwa para karyawan merasa kurang puas dengan upah yang mereka terima dari perusahaan. Karyawan merasa kurang puas dengan upah mereka bekerja saat ini dan mengharapkan upah yang lebih tinggi dengan berganti profesi pekerjaan. Hal ini perlu diperhatikan oleh perusahaan karena kepuasan karyawan merupakan faktor penting untuk mempertahankan karyawan yang berpengalaman pada perusahaan dan mengurangi keinginan karyawan untuk meninggalkan perusahaan.

Sedangkan keinginan karyawan untuk mencari pekerjaan baru di bidang yang berbeda pada perusahaan lain, dalam variabel turnover intention, memiliki tingkat yang paling tinggi atau memiliki jawaban rata-rata paling tinggi. Hal ini menunjukkan bahwa ketika keadaan perusahaan membuat karyawan ingin memperoleh pekerjaan yang lebih baik sehingga semakin besar karyawan ingin keluar. Pemahaman ini muncul karena karyawan merasa sudah tidak memungkinkan lagi bekerja dengan keadaan perusahaan yang tidak memberikan apa yang dibutuhkan sebagai dasar usaha atau pekerjaan seperti mengejar jenjang karir yang lebih tinggi. Faktor inilah yang mendorong terjadinya turnover intention di PT XL Axiata Tbk Jakarta. Secara garis besar, karyawan memiliki kemungkinan untuk keluar dari perusahaan. Ini berdasarkan jawaban yang paling sering dipilih oleh karyawan pada pernyataan mengenai variabel turnover intention dengan nilai rata-rata 3,82.

\section{SIMPULAN}

Terdapat pengaruh secara parsial dan simultan antara stres kerja, beban kerja dan lingkungan terhadap turnover intention. Faktor yang paling berpengaruh terhadap turnover intention adalah stres kerja. Oleh karena itu hal utama yang mendorong karyawan untuk keluar dari perusahaan adalah tingginya tingkat stres kerja. Karyawan yang merasa stres dalam pekerjaannya kemungkinan besar akan keluar dari organisasi. Faktor kedua yang mendorong keinginan karyawan untuk keluar adalah beban kerja.

Stres kerja adalah salah satu faktor yang perlu diperhatikan dan perlu dipertahankan penangannya bagi PT XL Axiata. Perusahaan sebaiknya fokus pada karyawannya, dengan cara memberikan promosi jabatan yang lebih baik kepada karyawan yang mempunyai kinerja yang baik untuk perusahaan. PT XL Axiata juga sebaiknya memberikan sistem kerja tetap (permanen) terhadap karyawannya agar karyawan mendapatkan peluang untuk mengejar karir yang lebih tinggi seperti kenaikan jabatan dalam perusahaan.

Beban kerja merupakan pengaruh yang cukup besar terhadap turnover intention karyawan pada PT XL Axiata. Salah satu upaya yang dapat dilakukan oleh perusahaan untuk mengurangi beban kerja terhadap karyawan adalah dengan melakukan perekrutan karyawan baru yang berpengalaman karena karyawan di PT XL Axiata merasakan beban kerja yang berlebihan karena tugas-tugas yang diberikan terlalu banyak sehingga menyebabkan karyawan menggunakan jam istirahat untuk menyelesaikan tugas. Upaya lain yang dapat dilakukan PT XL Axiata adalah dengan memberikan upah terhadap karyawan yang lembur untuk menyelesaikan tugas. 
Lingkungan kerja karyawan harus pula menjadi perhatian PT XL Axiata Tbk Jakarta, karena dengan lingkungan yang nyaman maka karyawan dapat menyelesaikan pekerjaannya dengan baik dan akan berdampak pada kinerja perusahaan tentunya. PT XL Axiata juga harus tetap senantiasa menjaga lingkungan kerja karyawan agar tetap nyaman dan kondusif dengan mengatur suhu ruangan di tempat kerja sesuai dengan kondisi tubuh karyawan agar tidak terlalu dingin atau tidak terlalu panas.

Turnover intention timbul akibat rasa kurang puas karyawan terhadap pekerjaan dan perusahaannya. Angka turnover yang tinggi pada perusahaan mengindikasikan bahwa karyawan tidak betah bekerja di perusahaan yang bisa disebabkan oleh beberapa faktor yang dirasakan karyawan. Hal yang perlu diperhatikan oleh perusahaan adalah bagaimana agar karyawan dapat bertahan di perusahaan. Tekanan stres kerja yang tinggi, tuntutan peran dan sistem kerja menyebabkan karyawan tidak betah untuk menetap, sehingga dalam proses seleksi dan rekrutmen perusahaan harus lebih jeli dalam memilih karyawan apakah karyawan yang dipilih dapat bekerja dibawah tekanan dan cocok dengan budaya maupun sistem kerja di perusahaan. Dengan memperbaiki sistem seleksi dan rekrutmen diharapkan dapat mengurangi tingkat turnover pada perusahaan. Perusahaan perlu menganalisis dan mengembangkan lagi faktor-faktor lain yang dapat memengaruhi turnover intention karyawan dalam upaya mempertahankan karyawan yang berkompeten.

\section{DAFTAR PUSTAKA}

Quereshi, M.I., Jamil, R. A., Iftikhar, M., Arif, S., Lodhi, S., Naseem, I., Zaman, K., et. al (2013). Job stress, Workload, Environment and Emoloyees Turnover Intentions: Destiny or Choice. Jurnal of Management Info, 65(8).

Quereshi, M. I., Iftikhar, M., Abbas, S.G., Khan, K., Zaman, K. (2013). Relationship Between Job Stress, Workload, Environment and Employees Turnover Intentions: What We Know, What Should We Know. Jurnal of Management Info, 23(6).

Robbins, S. P., Judge, T. A. (2008). Perilaku Organisasi. Edisi 12 buku 1. Jakarta: Salemba Empat.

Salleh, A. L., Bakar, R. A., Keong, W. K. (2008). How Detrimental is Job Stress? : A Case Study Of Executives in the Malaysian Furniture Industry. International Review of Business Research Papers, 4(5).

Sedarmayanti. (2007). Manajemen Sumber Daya Manusia. Edisi 1. Bandung: RefikaAditama.

Sedarmayanti.(2011). Tata Kerja dan Produktivitas Kerja: Suatu Tinjauan Dari Aspek Ergonomi Atau Kaitan Antara Manusia Dengan Lingkungan Kerjanya. Cetakan Ketiga. Bandung: Mandar Maju

Sekaran, U. (2006). Metodelogi Penelitian Untuk Bisnis. Edisi 4. Jakarta: Salemba Empat.

Soleman, A. (2011). Analisis Beban Kerja Ditinjau Dari Faktor Usia Dengan Pendekatan Recommended Weiht Limit. ARIKA, 5(2).

Staffelbach, B. (2008). Turnover Intent. Diploma Thesis. University of Zurich, Swiss.

Widjaja, D. C. (2012). Analisis Persepi Employee Empowerment Terhadap Employee Turnover Intention Di Hotel $X$, Kupang, Nusa Tenggara. Jurnal Management Perhotelan, 4(2). 